\title{
EQUALITY OF OPPORTUNITY AND INVESTMENT IN CREDITWORTHINESS
}

\section{PETER P. SWIRE†}

The Community Reinvestment Act (CRA) was enacted in 1977. ${ }^{1}$ Its vague provisions initially resulted in only modest enforcement efforts by regulators, and the law received scant attention from academics. ${ }^{2}$ The CRA was reinvigorated in the late $1980 \mathrm{~s}$. The change occurred in part when the statute was amended in 1989, notably by requiring banks' CRA ratings to be disclosed publicly. ${ }^{3}$ Perhaps just as importantly, the change occurred as regulators made enforcement of the Act a higher priority, both before and especially after the election of President Clinton in 1992.4 This second incarnation of the CRA has created a furor in the banking community ${ }^{5}$ and has attracted a rapidly growing body of academic literature. $^{6}$

The time is thus opportune for a critical examination of the CRA, as Professor A. Brooke Overby performs in The Community Reinvestment Act Reconsidered.' In this short Paper, I cannot comment on many of the interesting and provocative points made in Overby's article. Instead, I will consider some implications of two of her points. First, Overby makes the linguistically surprising argument that the CRA "has little, if anything, to do with 'com-

† Associate Professor of Law, University of Virginia. I would like to thank Mary Ann Case, Paul Mahoney, and Rip Verkerke for comments. Anjana Baluja provided essential research assistance on the statistics.

${ }^{1}$ Community Reinvestment Act of 1977, Pub. L. No. 95-128, 91 Stat. 1147 (codified as amended at 12 U.S.C. $\$ \$ 2901-2907$ (1988 \& Supp. V 1993)).

${ }^{2}$ For an excellent account of the early history of the CRA, see Robert C. Art, Social Responsibility in Bank Credit Decisions: The Community Reinvestment Act One Decade Later, 18 PAC. L.J. 1071 (1987).

${ }^{3}$ Financial Institutions Reform, Recovery, and Enforcement Act of 1989, Pub. L. No. 101-73, tit. XII, $\S 1212$ (b), 103 Stat. 183, 527 (codified as amended at 12 U.S.C. $\S 2906$ (b) (Supp. V 1993)).

${ }^{4}$ See Peter P. Swire, The Persistent Problem of Lending Discrimination: A Law and Economics Analysis, 73 TEx. L. REV. 787, $854-55$ (1995) (describing the Clinton Administration's efforts to enforce the CRA).

${ }^{5}$ Professor Overby notes, for instance, that regulators received over 6700 comments on the proposal for revised CRA regulations in 1993. See A. Brooke Overby, The Community Reinvestment Act Reconsidered, 143 U. PA. L. REV. 1431, 1433 n.15 (1995).

${ }^{6}$ See id. at $1436 \mathrm{nn} .27 \& 28,1437 \mathrm{n} .30$ (citing sources).

7143 U. PA. L. REV. 1431 (1995). 
munity." Overby's examination of the legislative history shows that the CRA as introduced was targeted especially at disinvestment, which occurs when the deposits taken from a community are not invested back into that community. ${ }^{9}$ Overby shows how these disinvestment provisions were largely stripped from the law as enacted. ${ }^{10}$ The CRA can thus plausibly be understood as primarily directed toward the problem of redlining, which occurs when banks or other lenders refuse to loan based on the neighborhood, rather than on the characteristics of a particular borrower.

This emphasis on redlining, in turn, leads directly to Overby's second point, that the CRA should be understood as seeking the goal of equality, and especially equality of opportunity for those seeking credit. ${ }^{11}$ I agree that equality of opportunity provides a vital reason for supporting the CRA and fair lending initiatives more generally. This Paper will explore some aspects of equality of opportunity in lending.

In particular, I will consider the implications of borrowers' investment in creditworthiness. Part $I$ of this discussion develops a model showing how borrowers in a group that is discriminated against will not receive the same return on their efforts to prove their creditworthiness as other borrowers. The model predicts that borrowers in the discriminated-against group will, on average, not educate themselves as much about the financial system and will not make costly efforts to conform to behavior that lenders prefer.

To get an intuitive feel for the investment in creditworthiness model, consider a borrower's attitude in two settings-an efficient lending market that she expects to visit repeatedly versus a discriminatory market that she believes is likely to deny her credit in the future. In the efficient market, the long-run advantages of learning about the financial system and making timely payments are obvious. By contrast, a person may reasonably decide not to bother participating in a lending market that seems discriminatory. And, if a person is in fact approved for a loan in such a market, greater

\footnotetext{
${ }^{8} I d$. at 1438.

${ }^{9}$ See id. at 1453-55.

${ }^{10}$ See id. at 1455 (stating that the original "reinvestment moorings [of the CRA] began to crumble").

"See id. at 1497-1505. In this short Paper, I will not try to define equality of opportunity in any detail. A useful short definition is Rawls' formulation "that those with similar abilities and skills should have similar chances." JOHN RAWLS, A THEORY OF JUSTICE 73 (1971).
} 
incentives exist to take the money and run, or at least not to strive so valiantly to pay on time.

Such responses from borrowers can reinforce discriminatory practices of lenders. This problem of the "self-fulfilling prophecy" is familiar in redlining discussions. ${ }^{12}$ Michael Klausner's contribution to this Symposium, for instance, discusses two self-reinforcing effects. ${ }^{13}$ The first effect is based on information externalities. Where there are few comparable transactions in a neighborhood, lenders lack needed information about the neighborhood. ${ }^{14}$ Lenders thus consider the neighborhood increasingly risky as transactions diminish, and they further reduce their loans there. The second effect Klausner calls a neighborhood externality-lenders are reluctant to do business in a neighborhood unless other lenders also do business there. ${ }^{15}$ Any one lender does not wish either to make all the loans to a neighborhood or to suffer a loss in the value of collateral when liquidity dries up. Thus, a lender perceives higher risk when other lenders pull out. As some lenders no longer do business in a neighborhood, other lenders have a reason to leave, too.

The investment in creditworthiness model lets us understand an additional self-reinforcing pattern in credit markets. The model shows that borrowers in a discriminated-against group have less incentive to make themselves attractive to lenders. Over time, these actions by borrowers can reinforce the initial discrimination by lenders. The result can be a downward spiral in which the discriminated-against group becomes far less involved in credit markets than other groups. The investment in creditworthiness model also reinforces the geographic explanations for self-fulfilling prophecies. To the extent those geographic explanations depend on borrower behavior, ${ }^{16}$ the model here gives a more general account of why

${ }^{12}$ See, e.g., Donald Phares, Racial Change and Housing Values: Transition in an Inner Suburb, 52 Soc. SCI. Q. 560, 565 (1971) (describing the self-fulfilling prophecy for neighborhood lending).

${ }^{13}$ See Michael Klausner, Market Failure and Community Investment: A MarketOriented Alternative to the Community Reinvestment Act, 143 U. PA. L. REv. 1561, 156571 (1995).

${ }^{14}$ See id. at 1569-70 (discussing the "declining spiral" of the home-mortgage lending market in low-income communities).

${ }^{15}$ See id. at 1570-71. The effect may be more precisely understood as a problem arising from strategic interaction among lenders. See Swire, supra note 4, at 825 (describing how banks' private incentives may lead to a publicly suboptimal level of lending to a community).

${ }^{16}$ See Swire, supra note 4, at 24 (describing the negative effects that owners or 
borrowers in a discriminated-against group would rationally invest less in creditworthiness over time.

The model of lower investment in creditworthiness would apply generally to any group that is the target of discrimination by lenders. The model may be of particular interest, however, when applied to the experience of blacks in the United States. There is an unquestioned history of public and private discrimination against blacks in lending markets. ${ }^{17}$ There is considerable evidence, although subject to more debate, that lending discrimination against blacks persists today. ${ }^{18}$ In the face of this discrimination, it is possible that blacks have, on average, reasonably decided not to enter credit markets as often as whites and have made fewer efforts to conform their behavior to lenders' preferences.

Part II of this Paper explores some implications of the creditworthiness argument as applied to black households in the United States. Part III presents empirical evidence that supports the predictions of the investment in creditworthiness model. In 1989, $44.6 \%$ of black households had checking accounts, compared to 79.9\% of all other households. ${ }^{19}$ This Paper presents a series of regressions showing that race is a highly significant factor in explaining which households have checking accounts, even after accounting for relevant economic and demographic variables. The essential point is that failing to have a checking account would seem to be evidence of a low level of investment in creditworthiness. The much higher rate of black households without checking accounts thus fits the model's prediction of lower investment in creditworthiness. Other explanations exist for the data, but it is interesting to note that many of them presuppose other forms of significant continuing discrimination in lending markets.

The conclusion returns to the question of equality of opportunity in lending markets. The investment in creditworthiness model helps illuminate the difficulty of even approaching that goal. Rational borrower behavior can magnify the effects of discrimination by lenders, potentially leading to the self-reinforcing pattern already discussed. The checking account data, which has not

borrowers who fail to maintain their properties can have on the value of neighboring properties).

${ }^{17}$ See id. at 793-802.

${ }^{18}$ See id. at 806-14.

${ }^{19}$ Interview with Gerhard Fries, Statistician, Division of Research \& Statistics, Federal Reserve Board, in Washington, D.C. (July 14, 1994) [hereinafter Fries Interview]. 
previously been the subject of careful analysis, offers additional reasons for believing that equal opportunity is not available to blacks in credit markets today.

\section{A MODEL OF UNDERINVESTMENT IN CREDITWORTHINESS}

The underinvestment in creditworthiness model draws on the underinvestment in human capital model developed by Shelly Lundberg and Richard Startz in employment markets. ${ }^{20}$ Lundberg and Startz's model assumes that workers have both innate and acquired characteristics that determine their productive abilities. Each worker acquires human capital to the point where the marginal cost of more training equals the marginal benefit in the form of higher wages. ${ }^{21}$ "Human capital" here includes not only formal schooling, but also, in the words of Kenneth Arrow, the "more subtle types of personal deprivation and deferment of gratification which lead to the habits of action and thought that favor good performance" in a job. ${ }^{22}$

Lundberg and Startz explore the effects on employees of "statistical discrimination," which involves use of a general category, such as race or neighborhood, to reduce the costs of particularized inquiry into an individual's qualifications for a job or a loan. ${ }^{23}$ They assume that employers are provided with test scores that provide information about each worker's marginal product, and that employers can identify each employee as either white or black. ${ }^{24}$ Lundberg and Startz show mathematically that the wage offered to a worker will depend on the individual's test score as well as some

${ }^{20}$ See Shelly J. Lundberg \& Richard Startz, Private Discrimination and Social Intervention in Competitive Labor Markets, 73 AM. ECON. REV. 340 (1983). Lundberg and Startz develop their model to show the possible efficiency of government regulation of the labor market. This Paper does not assess the efficiency of regulation, but instead shows how lower investment in creditworthiness can magnify the effects of any initial level of discrimination.

${ }^{21}$ The marginal cost of investment rises due to "diminishing returns to time and money spent on training activities and increasing disutility of foregone leisure." Id. at 343.

${ }^{22}$ Id. at 342 (quoting Kenneth J. Arrow, The Theory of Discrimination, in DiSCRIMINATION IN LABOR MARKETS 27 (Orley Ashenfelter \& Albert Rees eds., 1973)).

${ }^{23}$ See Edmund S. Phelps, The Statistical Theory of Racism and Sexism, 62 AM. ECON. REV. 659 (1972); Cass R. Sunstein, Why Markets Don't Stop Discrimination, 8 Soc. PHIL. \& POL'Y 22, 26 (1990); see also Swire, supra note 4, at 822 (noting difficulty of distinguishing profit-enhancing statistical discrimination from profit-reducing taste for discrimination or from prejudice).

${ }^{24}$ See Lundberg \& Startz, supra note 20, at 344. 
adjustment for membership in the group. ${ }^{25}$ The source of the adjustment can be quite subtle-Lundberg and Startz assume that both groups have the same innate ability and that the test score gives the same average result. ${ }^{26}$ Their model nonetheless shows the effects of discrimination simply when the random error in the test score is greater for one group (blacks) than for the other (whites). ${ }^{27}$ Because the test score, on average, is not as precise, blacks appear riskier to employers; therefore profit-maximizing employers will offer blacks lower wages. ${ }^{28}$

Under the Lundberg and Startz model, white workers will receive larger raises for increased test scores, as well as higher average raises. ${ }^{29}$ Because they are more highly rewarded for improved test scores, white workers will rationally invest more in human capital-they receive a greater marginal return from each unit of education than do black workers. Generalizing from the Lundberg and Startz model, Professor Cass Sunstein explains how underinvestment in human capital can result whenever significant discrimination exists in a labor market due to racial animus or various forms of profit-maximizing discrimination. ${ }^{30}$ Sunstein writes: "Decisions about education, training, drug use, tradeoffs between work and leisure, and employment programs will be affected by existing patterns of discrimination." ${ }^{31}$ For example, if a profession such as medicine is closed to blacks or women, their expected return from training for that profession will be lower.

A similar pattern can exist in credit markets-it may be that blacks and other minorities rationally invest less in creditworthiness than do whites. To understand this possibility, we must first better understand what is meant by investment in creditworthiness, which has both an educational and a behavioral component.

The educational component includes information about how the financial system operates and how to gain benefits by appropriately borrowing. Aspects of such education might include a working knowledge of how to balance a checkbook, make a family budget, shop for interest rates, and assess the tax consequences of various actions. A consumer must learn how to borrow enough to establish

\footnotetext{
${ }^{25}$ See $i d$.

${ }^{26}$ See id.

${ }^{27}$ See id.

${ }^{28}$ See id.

${ }^{29}$ See id.

${ }^{30}$ See Sunstein, supra note 23, at 29.

${ }^{31}$ Id.
} 
good credit without borrowing more than he can afford. ${ }^{32}$ The potential complexity of the educational task is illustrated by a borrower on an adjustable-rate mortgage who is faced with a potentially bewildering array of terms for allocating interest-rate risk between borrower and lender. ${ }^{33}$ The investment of time and effort in learning how best to conduct one's personal finances can thus be substantial.

The educational component also includes learning how to act after becoming involved in the financial system. Borrowers must learn what behavior will be rewarded in order to act in ways that lenders prefer. For example, consumers need to understand the consequences of actions such as failing to pay debts, writing bad checks, entering personal bankruptcy, and changing jobs frequently. ${ }^{34}$ Consumers might benefit from knowing about other behavior lenders prefer, such as coming forward to negotiate a payment schedule when full payment is not possible.

The behavioral component of investment in creditworthiness includes a consumer's decision whether to become involved in the financial system and how that consumer acts if and when she becomes involved. The economically rational borrower will weigh the personal benefits of certain behavior against its costs. Imagine a borrower facing burdensome payments on a loan. The borrower may know that making the loan payment will create some incremental improvement in her credit history. The benefit of that increment will be weighed against the costs of paying back the loan. Costs may include the need to scrimp on consumption, work a second job, borrow money from family or friends, or make other extraordinary efforts to pay the loan. The tradeoff will typically be between an improved credit rating in the future (and thus higher expected future consumption) and increased consumption today. In short, a borrower's rational level of investment in creditworthiness includes a rational level of investment in education about the

\$2 In modern-day America, this issue can often arise for a young person facing the freedom of her first credit card without appreciating the difficulty of paying off the account balance once it has reached the pre-set limit.

${ }^{33}$ The variety among adjustable-rate mortgages is reflected in their classification into hundreds of different varieties for purposes of sale on the secondary market. See, e.g., James H. Saft, Fannie Simplifies Classifying of ARM Securities, AM. BANKER, Feb. 14, 1995, at 17 (Fannie Mae cuts number of subtypes of adjustable-rate mortgages from 450 to 189 ).

${ }^{34}$ See Swire, supra note 4, at 837 (describing recent regulatory initiative to encourage lenders to be more willing to loan to people who have been steadily employed but have often changed jobs). 
financial system and a rational level of effort to conform to the preferences of lenders, notably by maintaining a good credit record. ${ }^{35}$

The next step in modeling underinvestment in creditworthiness is to examine the implications of lending discrimination. In the Lundberg and Startz model, workers decide how much to invest in human capital, greater investment in human capital leads to higher wages, and whites get a greater payback from such investment than blacks. ${ }^{36}$ If the labor market model were transposed exactly into the credit market, borrowers would decide how much to invest in creditworthiness, greater investment in creditworthiness would lead to a lower interest rate on loans, and whites would get a greater payback from such investment than blacks. The model for credit markets, however, should be slightly different. A model for who gets mortgage loans does not usually assume that more creditworthy borrowers simply get a better interest rate. ${ }^{37}$ Rather, the interest rate is set by the market, and lenders focus on the likelihood of default. $^{38}$ In the lending model, a borrower will get a loan when her score on a creditworthiness index is above some threshold (that is, when the likelihood of default is low enough), and will not receive a loan when her creditworthiness index is below the threshold. As with the Lundberg and Startz model, assume that whites and blacks have, on average, the same innate ability and that the test score gives the same average result. ${ }^{39}$ Also assume that the test for creditworthiness has a greater random error for blacks, and so they appear riskier to lenders. Each borrower's index will thus be a function of his individual score and an adjustment for his membership in the riskier (black) or less risky (white) group. As before, the average return on investment in creditworthiness will be higher for

35 The Lundberg and Startz model does not include any explicit costs for the employee analogous to the educational component of creditworthiness. The model presented here, by contrast, discusses the possibility of significant costs to consumers of educating themselves about the financial system, including learning what behavior lenders prefer. The larger these costs, the greater the expected differential investment in creditworthiness by groups that are the target of discrimination.

${ }^{36}$ See Lundberg \& Startz, supra note 20, at 344.

${ }^{37}$ See Geoffrey M.B. Tootell, Defaults, Denials, and Discrimination in Mortgage Lending, NEW ENG. ECON. REV., Sept.-Oct. 1993, at 45, 47.

${ }^{38}$ See id. at 46 . The lender would also care about the size of the default if it occurs. See id. at 46-47.

${ }^{39}$ If the average score for blacks were lower for some reason, lenders would have a stronger statistical basis for discriminating against blacks. The difference in incentives to invest in creditworthiness would also increase. 
whites than for blacks, resulting in a lower rational level of investment in creditworthiness for blacks. ${ }^{40}$

\section{EXTENDING THE MODEL OF REDUCED INVESTMENT IN CREDITWORTHINESS}

The previous discussion showed how the model of underinvestment in human capital, based on statistical discrimination by employers, would apply, suitably modified, in lending markets. This Part extends that model, showing why underinvestment in creditworthiness can occur in situations beyond the specific sort of statistical discrimination included in the previous model.

One important insight is that underinvestment does not logically depend on actual discrimination by lenders. Rather, people's decisions about how much to invest in creditworthiness would seem to depend on their perception of discrimination, rather than on the level of discrimination itself. ${ }^{41}$ The focus of investment in creditworthiness is on the behavior of borrowers, so the beliefs of borrowers determine their actions.

Evidence suggests that many blacks believe significant lending discrimination still exists. There has been widespread publicity of reports under the Home Mortgage Disclosure Act that blacks with the same income are turned down more than twice as often for home mortgages as whites. ${ }^{42}$ Surveys show perceptions of wide-

${ }^{10}$ Because of differences in labor markets and credit markets, exceptions to the predicted underinvestment could occur. In the labor model, greater investment in human capital smoothly leads to higher wages. In the credit model, by contrast, greater investment in creditworthiness may or may not result in a borrower's clearing the threshold score required by a lender. For any given threshold, borrowers who know the threshold and are near it will have more incentive to invest in creditworthiness. If discrimination placed many black borrowers near the threshold for a category of loan, then the result conceivably could be greater average investment in creditworthiness.

A different possibility is that discrimination could result in greater investment in creditworthiness for some blacks. In the face of significant discrimination, especially when the consumer does not know the degree of discrimination, the only way to assure oneself credit may be to adopt a "cleaner than clean" strategy that maintains creditworthiness at or above all likely thresholds.

${ }^{41}$ I do not try to resolve here the question of how, and for how long, perceptions of discrimination can persist in the absence of actual discrimination by lenders. At the current time, academic experts are hotly debating the continuing amount of lending discrimination. See Swire, supra note 4, at 806-14 (discussing empirical disputes about continuing discrimination). In the presence of such uncertainty, there is little reason to believe that ordinary consumers will somehow know the "true ${ }^{n}$ level of lending discrimination.

${ }^{12}$ See infra text accompanying notes 65-67 (discussing HMDA data). Lending 
spread lending discrimination. ${ }^{43}$ More generally, the clear history of public and private lending discrimination provides concrete experiences for many black families that support a perception of continuing discrimination today. ${ }^{44}$

The history of discrimination is important for another reason. Creditworthiness, like human capital, is acquired over time and sometimes over generations. In a family with established credit, a young person can get advice on how to start a credit history, cosignatories on a credit card or mortgage, and helpful gifts when personal resources are not enough to pay the bills. Compare the family that has experienced discrimination and perceives continued discrimination: cosignatories are less likely, the young person may be taught suspicion of lenders, and there may be less willingness to use family resources in the short run to maintain credit in the long run. A young person in the latter family is not disadvantaged simply by being poorer, although past discrimination would tend to produce lower net worth. She is also disadvantaged because ongoing discrimination lowers her and her family's knowledge about the financial system as well as their rational level of effort to maintain creditworthiness. ${ }^{45}$

discrimination and the perceptions of discrimination have been discussed in numerous recent congressional hearings. See, e.g., Availability of Credit to MinorityOwned Businesses, Memorandum from Stephen L. Neal, Chairman of the House Subcommittee on Financial Institutions Supervision, Regulation and Deposit Insurance to Members and Their Staff, Oct. 6, 1994, $1994 \mathrm{WL} 738144$, at *1 ("Many Americans believe that minority-owned small businesses face credit availability challenges over and above those experienced by their majority-owned counterparts.").

${ }^{43}$ See, e.g., Eugene Carlson, Turned Down, WALl ST. J., Feb. 19, 1993, at R1, R5 (reporting the results of a Roper poll of black business owners finding a perception of racial discrimination in lending); Jay Mathews, Learning from the Loan Arrangers, WASH. POST, July 19, 1994, at C1, C3 (citing examples of profitable black business people who believe they are facing lingering racism in lending).

${ }^{44}$ For instance, prior to 1962-when President Kennedy issued an executive order to the contrary- "it was required by the Federal Housing Authority that public housing be classified for occupancy by a particular race." Bradley v. School Bd. of Richmond, 338 F. Supp. 67, 219 (E.D. Va.), rev'd, 462 F.2d 1058 (4th Cir. 1972), affd sub nom. School Bd. v. State Bd. of Educ., 412 U.S. 92 (1973). An example in the private sector comes from 1977 training materials issued by the American Institute of Real Estate Appraisers, which gave the following example of appropriate appraisal analysis: "The neighborhood is entirely Caucasian. It appears that there is no adverse effect by minority groups." Art, supra note 2, at 1078 n.26 (quoting unspecified 1977 training materials of the American Institute of Real Estate Appraisers). See generally Swire, supra note 4, at 793-802 (describing history of lending discrimination).

${ }^{15}$ As with family history, the neighborhood of a person can be relevant to their investment in creditworthiness. To the extent a person lives in a neighborhood cut 
This family situation, and the perceptions of continued discrimination, are part of a larger set of factors that shape an individual's decision about how much to invest in creditworthiness. Whereas the original model showed how lower investment can occur due solely to statistical discrimination by lenders, lower investment in creditworthiness can result from any source of actual or perceived discrimination, so long as blacks' expected payoff from investment in creditworthiness is less than whites.'

Before turning to the evidence about checking accounts, consider one other implication of the model-it predicts what has been called the "thicker file" syndrome. ${ }^{46}$ Some loan applications are easily accepted or rejected. For the large middle category, there is reportedly some tendency for white applicants to have a "thicker file" than black applicants. It has previously been suggested by, among others, Federal Reserve Governor Lawrence Lindsey, that lending officers may work with the white applicants more extensively, such as by getting explanatory letters for bad credit history or documenting nontraditional sources of income. ${ }^{47}$ The investment in creditworthiness model, in contrast, suggests the possibility that it is borrower rather than lender behavior that would explain thicker files. If white applicants expect to get credit, they may be more willing to build a thick file by investing time and energy in overcoming obstacles. By contrast, if minority applicants enter the process perceiving that discrimination exists, obstacles may seem more like pretexts for a loan denial. The perception of discrimination can once again contribute to differential outcomes. Here and elsewhere, my intent is emphatically not to blame any persons for failure to invest in creditworthiness. Instead, the model points out rational reasons for less investment by people who actually are or who perceive themselves to be subject to discrimination.

off from many aspects of the financial system, and dependent instead on pawn shops and check cashing outlets, it will be more expensive for that individual to learn how to participate in banks and other principal parts of the financial system.

${ }^{46} \mathrm{Jim}$ McTague, The Bias Charge Against Banks Hangs on Pretly Slim Evidence, AM. BANKER, Apr. 26, 1993, at 4 ("There is fairly solid, albeit anecdotal, evidence that marginal white applicants have thicker loan files than marginal blacks." (quoting Federal Reserve Governor Lawrence Lindsey)). The factual basis for this statement, however, has been questioned. See $i d$. ( ${ }^{\text {" }}[\mathrm{I}] \mathrm{t}$ is absurd and unfair to rely on the case of one thrift ... to generalize about every depository institution in the country.").

${ }^{17}$ See id. (recounting Lindsey's conclusion that banks investigate whites more than blacks in an effort to find mitigating circumstances justifying a loan to a marginally qualified borrower). 


\section{The EMPIRICAL Evidence About Checking Accounts}

\section{A. Why Checking Accounts May Be Relevant to Investment in Creditworthiness}

Perhaps the most interesting information about investment in creditworthiness comes from Federal Reserve data on households and checking accounts. A nationwide 1989 survey by the Federal Reserve found that only $44.6 \%$ of black households, in contrast to $79.9 \%$ of all other households, had checking accounts. ${ }^{48}$ The regression analysis presented here establishes that race is a statistically significant factor in explaining who has checking accounts, even after controlling for such factors as income, net worth, education, age, and residence in a metropolitan area. This finding is robust across a range of models.

An important task is to assess the implications of the finding that race is a significant predictor of which households have checking accounts. My first claim is that the disparate rate of checking accounts is evidence of disparate investment in creditworthiness. My second claim is that the lower investment in creditworthiness should be understood as a rational response to historical or current lender discrimination. Below, I will discuss critiques of both claims, and I will modify them somewhat in light of those critiques. Here, I suggest the first claim may be true for both the educational and behavioral components of creditworthiness.

First, and perhaps most importantly, not having a checking account may be important evidence of lack of education about the financial system. ${ }^{49}$ For those without a checking account we might imagine a fairly low average level of education about how to get

${ }^{48}$ For a discussion of the data provided in the Federal Reserve survey, see infra, Technical Appendix. Additional information about this survey was obtained from the Fries Interview. See supra note 19. The nonblack households include white, Asian, and Hispanic households.

49 The Federal Reserve Survey defined checking accounts broadly to include conventional checking accounts, NOW accounts, and money market accounts used for checking. See Arthur Kennickell \& Janice Shack-Marquez, Changes in Family Finances from 1983 to 1989: Evidence from the Survey of Consumer Finances, 78 Fed. Res. Bull. 1, 7 (1992). 
loans and maintain a good credit history. ${ }^{50}$ Substitutes for checking accounts, such as postal money orders or check-cashing shops, provide a way to conduct individual transactions, but do not teach a consumer how to maintain the long-term financial relationships and documentation that are important to lenders. In a world in which roughly $55 \%$ of black households lack a checking account, and in which $80 \%$ of other households have them, the inference that black households on average have not learned as much about how to participate in the financial system seems warranted. The results stay the same when one considers a much longer list of financial assets, including savings accounts. ${ }^{1}$

By contrast, having a checking account is evidence of education about the financial system. The consumer has taken the initial step to enter a bank and choose the sort of account that she desires. Maintaining a checking account is itself an educational process, confronting the consumer with a monthly record of the account, encouraging the consumer to balance the checkbook, and penalizing the consumer with stiff fees if she mismanages the account. Having a checking account may also be an important step on the way to a consumer's further education about the financial system, opening the consumer's eyes to additional banking or investment accounts and services.

Turning to the behavioral component of creditworthiness, the lack of a checking account itself can affect a person's ability to get a loan or maintain a good credit history. The lack of a checking account will typically mean a less clearly documented financial history, making it more difficult for the borrower to answer a lender's demands for information. The absence of clear records that a checking account generates makes it more difficult for a borrower to keep track of what bills have been paid, increasing the likelihood of missed payments. Furthermore, getting a home loan without having a bank account may be prohibitively difficult. Lenders often require a substantial cash reserve in a bank account

${ }^{50} \mathrm{~A}$ person without a checking account, but with the right sort of personal property, can hope to get a loan at a pawn shop. Such loans, however, do not typically help establish a credit record and would not seem to provide as much experience in personal budgeting as the payment of regular loan obligations.

${ }^{51}$ At least one of a longer list of financial assets was held by $60.9 \%$ of black households and $91.4 \%$ of all other households. Fries Interview, supra note 19 . The list included checking accounts, savings accounts, money market accounts, certificates of deposit, retirement accounts, stocks, bonds, nontaxable bonds, trusts, and "other" assets. See Kennickell \& Shack-Marquez, supra note 49, at 5. 
at the time of closing. Lenders are skeptical of down payments made with "mattress money"-money whose source before the closing is not clearly documented. ${ }^{52}$ By contrast, a well-maintained checking account will help show that a borrower's sources of income are steady and legitimate, and the monthly account statements will often help answer specific questions posed by lenders. Having an established bank account can thus be important in a variety of ways to satisfying lenders' requirements, which comprise the behavioral component of investment in creditworthiness.

Having a checking account thus seems relevant evidence for both the educational and behavioral aspects of creditworthiness. The available data show a very wide gap between blacks and whites with regard to maintaining checking accounts. ${ }^{53}$ A chief goal of the statistical analysis presented here is to determine whether the lower rate of checking accounts for blacks is explained by economic and other factors that happen to be correlated with race. A first step is to see whether race is an important factor after correcting for economic variables-income and net worth-that one would expect to be linked to having a checking account. Black families have lower average incomes than other American families, ${ }^{54}$ and

52 See James H. Saft, GE, 1st Interstate Negotiating Leeway on Iffy Loans, AM. BANKER, Mar. 31, 1994, at 10 ("Mattress money is funds that do not come from bank accounts or other easily traced sources. Lenders shy away from mattress cash-often used by immigrant borrowers-for fear that it may actually be a loan."). An additional concern with mattress money is that it implicates money laundering restrictions on the use of cash. See 26 U.S.C. $\$ 6050$ I (1988 \& Supp. V 1993) (requiring reporting to Internal Revenue Service of cash transactions in excess of $\$ 10,000$ ).

${ }^{53}$ The raw data in the 1989 Survey data showed that $50.9 \%$ of black households and $93.5 \%$ of white households actually sampled had checking accounts. See infra Technical Appendix. These results overstate the actual levels of checking accounts, because the Survey over-sampled from high-income households. See Kennickell \& Shack-Marquez, supra note 49 , at 17 . The Federal Reserve has estimated that $79.9 \%$ of all nonblack households had checking accounts in 1989 , compared with $44.6 \%$ of black households. Fries Interview, supra note 19. A similar 1992 Federal Reserve Survey found that $93.1 \%$ of white households had transaction accounts, but only $67.5 \%$ of "Nonwhite or Hispanic" households, including black, Hispanic, or Asian families. See Arthur B. Kennickell \& Martha Starr-McCluer, Changes in Family Finances from 1989 to 1992: Evidence from the Survey of Consumer Finances, 80 Fed. Res. Bull. 861, 869 (1994). The comparable figures for 1989 were similar: 92.3\% for white households, and $63.7 \%$ for Nonwhite or Hispanic households. See id. at 868. White households thus had higher rates of checking accounts than the combined population of Hispanic and Asian households, who in turn had higher rates than black households.

${ }^{54}$ The mean income for black families in 1989 was $\$ 19,800$ and the median was $\$ 12,000$. By comparison, the mean for all other families (including whites, Asians, and Hispanics) was $\$ 38,000$ and the median was $\$ 26,800$. Fries Interview, supra note 
the net worth of black families is even lower. ${ }^{55}$ Perhaps, after correcting for lower income and net worth, black families are as likely as white families to have checking accounts.

The statistics do not support such a conclusion. The regression in Model 1, as reported in Table II of the Appendix, shows that race is statistically significant in explaining checking accounts at the one percent level. ${ }^{56}$ Income and net worth are similarly significant, although the coefficient for the race variable is greater than for either income or net worth, indicating that an increase in the race variable creates a greater increase in the likelihood of having a checking account. ${ }^{57}$

A similar situation exists when one adds other variables that might be thought important to predicting whether a family has a checking account. In every regression run, race was statistically significant at the one percent level. ${ }^{58}$ Other variables that were always significant at the one percent level were increased income, increased age, and increased education. ${ }^{59}$ Net worth was sometimes significant at the one percent level and sometimes at the five percent level. ${ }^{60}$ The presence of a married couple in the household was significant at the five percent level. ${ }^{61}$ Current employment for the head of the household was sometimes significant at the five percent level. ${ }^{62}$ Living in a metropolitan area was not statistically significant. ${ }^{63}$

\section{B. Criticisms of the Link Between Checking Accounts and Investment in Creditworthiness}

The Federal Reserve data appear to establish that race is a significant factor in predicting which households have checking accounts. A low rate of checking accounts is itself evidence of low

19 (describing results of 1989 Federal Reserve Survey of Consumer Finances).

${ }_{55}$ The mean net worth for black families in 1989 was $\$ 45,900$, and the median was $\$ 4,000$. By comparison, the mean for all other families was $\$ 203,800$ and the median was $\$ 58,500$. Id.

${ }^{56}$ See infira Technical Appendix (Table II). Significance at the 1\% level means that there is less than a $1 \%$ chance that the result was due to chance, rather than to an actual effect of race on having a checking account.

${ }^{57}$ See id.

${ }^{53}$ See id.

${ }^{59}$ See id.

${ }^{6}$ See id.

${ }^{61}$ See id.

62 See id.

${ }^{63}$ See id. 
investment in creditworthiness-consumers without checking accounts are unlikely to be lenders' favorite customers. The large gap in checking accounts between black and other households is also what might be expected under the model developed in Part I and extended in Part II-lender discrimination or the perception of lender discrimination may have produced a rational response by borrowers in the discriminated-against group, magnifying the effects of any initial discrimination.

The next task is to examine criticisms of the link between checking accounts and investment in creditworthiness. One sort of criticism goes to the quality of the data. As discussed in the Appendix, there are imperfections in the data used for the regressions. Although the Survey data is excellent in many respects, ${ }^{64}$ any conclusions must be treated with caution until other data sets have also been examined. The other categories of criticisms examined here are that the Survey omitted important variables, or that alternative hypotheses might explain the data better than the investment-in-creditworthiness model.

One criticism of the results reported here might be that the apparent correlation between race and checking accounts may be due instead to other variables not included in the data set. A similar criticism has been made about the Home Mortgage Disclosure Act (HMDA) data, which indicate that blacks are turned down for mortgages more than twice as often as whites with the same income. ${ }^{65}$ The HMDA data omit factors relevant to lenders such as credit history, employment history, and net worth. ${ }^{66}$ Consequently, the data have been justifiably criticized as providing a weak basis for assessing discrimination in mortgage lending. Compared with the HMDA data, the Federal Reserve survey used here to examine checking accounts is relatively immune to the omitted

${ }^{64}$ See infra Technical Appendix; see also supra note 53 (showing how differences in rates of checking accounts are large and consistent in Federal Reserve surveys over time).

${ }^{65}$ The latest HMDA figures are reported in Glenn B. Canner \& Wayne Passmore, Home Purchase Lending in Low-Income Neighborhoods and to Low-Income Borrowers, 81 Fed. Res. Bull. 71, 100 (1995) (noting that 34.0\% of black applicants were denied credit for conventional home purchase loans in 1993, compared with $15.3 \%$ of white applicants).

${ }_{66}^{6}$ See, e.g., Benjamin Zycher \& Timothy A. Wolfe, Mortgage Lending, Discrimination, and Taxation by Regulation, REgulation, No. 2, 1994, at 61, 64-65. However, the well-known study by the Federal Reserve Bank of Boston found evidence of disparate treatment even after correcting for variables omitted from the HMDA data. See Overby, supra note 5, at $1450 \mathrm{n} .81$. 
variable critique. Detailed information on many relevant characteristics is included in the data set, and the correlation with race is robust across a variety of models. ${ }^{67}$

Some potentially important variables, however, were not included in the Federal Reserve data. For instance, blacks may have fewer checking accounts due to a lack of financial institutions offering checking accounts in predominantly black neighborhoods. We might therefore wish to have data on accessibility to financial institutions. Alternatively, checking accounts may on average be less useful to blacks: perhaps vendors discriminate and are less likely to accept checks written by blacks, or perhaps more blacks live in neighborhoods where many vendors do not accept checks. We might therefore wish to have data that reflect the usefulness to a consumer of having a checking account. If these categories of data were available, we might find that the racial differences in having checking accounts would diminish or disappear.

In considering these omitted and potentially important variables, one notable feature is that they all rely on the assumption that blacks lack an equal opportunity to participate in the financial system. The core task of the CRA involved remedying the reduced availability of financial services in black neighborhoods. The refusal of vendors to accept checks written by blacks clearly violates antidiscrimination laws and deprives blacks of an equal opportunity to participate in transactions. The existence of black neighborhoods where vendors are disproportionately unwilling to accept checks, by assumption, means that blacks on average lack the opportunity others enjoy to use checking accounts and develop experience with financial services.

Additionally, all of the omitted variables, to the extent they are significant, may themselves be caused by a lack of investment in creditworthiness. That is, these potentially important variables may in part be the result of the magnification effect, where an initial level of discrimination was reinforced by rational borrower decisions not to invest in creditworthiness. Financial institutions may have abandoned a neighborhood because of a lack of borrowers who had invested sufficiently in creditworthiness. ${ }^{68}$ Profit-maximizing

${ }^{67}$ As shown in the Technical Appendix, the results reported here show that race is a significant variable after correcting for a substantial number of economic and demographic variables. The three regressions reported in Table II are a subset of a substantially larger number of regressions actually run on the data, all of which found race to be significant at the 1\% level. See infra Technical Appendix.

${ }^{68}$ As Klausner describes in his Paper, a low level of transactions in a neighbor- 
vendors could refuse to accept checks from blacks if their experience showed that blacks were less creditworthy, where the lower level of creditworthiness could once again be due to blacks' rational response to discrimination. ${ }^{69}$ The existence of neighborhoods where merchants do not accept checks could also occur because consumers there have not invested as much in creditworthiness, creating a downward spiral where few vendors accept checks so few consumers get checking accounts so even fewer vendors have reason to accept checks.

These potentially important, omitted variables thus may be significant in part because of rational lack of investment in creditworthiness by consumers who experience discrimination. There is also reason to question whether these variables, rather than the creditworthiness model, explain the large differences in rate of checking accounts. Each of the omitted variables raises empirical questions of its own. Consider the theory that the lower rate of checking accounts for blacks is due to financial institutions' decisions about where to locate offices rather than borrowers' decisions to invest less in creditworthiness. One recent study of financial institutions in Chicago for 1970, 1980, and 1990 found that "when relevant economic and demographic variables are accounted for, the racial and ethnic composition of a community's population is not significantly related to the number of financial institution offices." ${ }^{70}$ No one study can show a nationwide pattern of geographic access to financial services, but to the extent that the results of their study are generally true, the lack of financial institutions in predominantly black neighborhoods would not explain the much lower rate of checking accounts held by black households.

Similar empirical questions confront the theory that checking accounts are less useful on average to blacks. It may be fruitful to test the possibility that vendors discriminate against accepting checks from blacks. One model here could be Ian Ayres's study of discrimination in the purchase of automobiles, in which matched

hood can lead a profit-maximizing lender to refuse entirely to lend in that neighborhood. See Klausner, supra note 13, at 1570-71.

${ }^{69}$ Refusal to honor checks written by blacks, of course, could also be due to prejudice.

${ }^{70}$ George G. Kaufman \& Larry R. Mote, The Geographic Distribution of Financial Institutions in Chicago, ECON. PERSPECTIVES, Jan.-Feb. 1994, at 10, 25. The authors, however, caution against drawing general conclusions from their data: "The findings of the study are preliminary, apply only to Chicago, and cannot be generalized to other urban areas." Id. 
testers were sent to purchase new cars, and significant differences were found in the prices charged to women and minorities. ${ }^{11}$ Matched testers might similarly try to use checks to pay for goods and services. As for the possibility that blacks simply live where vendors do not accept checks, more empirical work would need to be done about geographic patterns of check usage. This geographic effect may be limited because many large vendors, such as utilities and large stores, have standard policies on accepting checks, irrespective of the residence of the consumer.

The discussion of omitted variables highlights the possibility that factors other than race explain the large differences in rates of having checking accounts. My response is that the variables may not be empirically significant; to the extent they are significant they may in part be caused themselves by lower investment in creditworthiness, and if they are significant they show a continuing lack of equality of opportunity.

The final criticism of the link between the checking account data and the investment in creditworthiness model accepts that race is a significant variable in explaining which households have checking accounts. This criticism offers an alternative theory that explains the significance of race by asserting that blacks simply have a lower taste for checking accounts, perhaps because, on average, they have some aversion to doing business with largely white-owned financial institutions. For instance, blacks might prefer not to have checking accounts at banks out of a distaste for past discrimination by these institutions.

In response to the taste theory, it is important to distinguish between blacks' internal tastes or preferences and their responses to external factors. The analysis here has focused on how external factors would influence a borrower's decision to have a checking account or otherwise invest in creditworthiness. These many external factors include the borrower's facing racial discrimination, earning lower income, or having less geographic access to financial services. Changes in the external factors lead to predictable changes in investment in creditworthiness. Differences in tastes are an important explanation of behavior only when one holds constant the effects of external factors. One of those external factors is whether the consumer is facing discrimination (or, equivalently for

"See Ian Ayres, Fair Driving: Gender and Race Discrimination in Retail Car Negotiations, 104 HARV. L. REV. 817, 818 (1991). 
our purposes, whether she perceives that she is facing discrimination). An aversion to banks based solely on a dislike for their historical practices would be taste-based, but an aversion based on perceptions of continuing discrimination would not. The model developed in this Paper emphasizes the external factors. This approach is consistent with usual economic practice, which generally assumes that different groups have similar tastes. ${ }^{72}$ The emphasis on external factors also makes sense where the gap between rates of checking accounts is so large. Vague references to differences in taste seem ill-suited to explaining such a large variation. ${ }^{73}$

\section{CONCLUSION}

Lending discrimination discussions to date-understandably so in light of the history of discrimination-have focused on the behavior of lenders. Individual consumers, however, react to the situations in which they find themselves. Where they are facing lending discrimination, it is predictable that they will adapt their behavior. The model of lower investment in creditworthiness shows how an initial level of lender discrimination can prompt less investment in creditworthiness by those who are discriminated against. Borrower reactions magnify the effects of lender discrimination. This lower level of investment in creditworthiness can reinforce profit-maximizing discrimination by lenders or invidious racial stereotyping, as rational action by borrowers can produce differences over time between groups. ${ }^{74}$

Two factors reinforce this magnification effect. First, borrower reactions depend on the perception of discrimination, rather than

72 See George J. Stigler \& Gary S. Becker, De Gustibus Non Est Disputandum, 67 AM. ECON. REV., Mar. 1977, at 76, 76 (arguing "that tastes neither change capriciously nor differ importantly between people").

${ }^{73}$ Similar responses apply to the possible theory that blacks have fewer checking accounts because on average they are "irrationally" failing to invest in creditworthiness. Irrational action is used in the economic sense of failing to achieve an individual's goals as efficiently as possible. Once again, economists would be reluctant to believe that large populations will differ substantially in their internal characteristics, such as taste or rationality. To give weight to the irrationality theory, economists or others would need to see advanced a particular explanation of why the black population on average would be less rational in achieving its goals than other groups. In addition, an explanation based on the internal characteristic of rationality is ill-suited to explaining the large variation in rates of checking accounts.

${ }^{74}$ See Sunstein, supra note 23, at 30-31 (discussing the synergistic effects of racial animus, rational discrimination by employers, and lower investment in human capital by employees). 
on discrimination itself. Second, creditworthiness, like human capital, is acquired over time and sometimes over generations. Put together, these two factors can lead to long-lasting effects on borrowers in a group that has been the historical target of discrimination. Even if lenders today no longer discriminate, the perception of discrimination can persist and borrowers in that group can face greater obstacles to achieving the educational and behavioral components of creditworthiness.

In applying the model to the United States, it is difficult to show empirically that differences in lending outcomes today are due to rational, lower investment in creditworthiness by blacks over time. As a first attempt to apply the model, this Paper has presented evidence based on the strikingly lower level of checking accounts now held by black households. The checking account data seem to indicate that black households today do invest less in creditworthiness-fifty-five percent of black households, as compared with twenty percent of all other households, do not take even the initial step into the financial system that a checking account represents. The regression analysis in this Paper presents new information about the checking account data, namely that race is a highly significant predictor of having a checking account, after correcting for a range of economic and demographic variables.

A more difficult issue is whether the low rate of checking accounts is due to lower investment in creditworthiness or to other explanations, such as a lack of financial institutions in predominantly black neighborhoods or a lower average usefulness of checking accounts for blacks. In examining these other explanations, this Paper gave reasons for thinking that they may not be empirically significant. To the extent they are significant, they may in part be caused themselves by lower investment in creditworthiness. These other factors, however, may indeed explain some of the difference in rates of checking accounts, and continued research would be helpful in sorting out the relative contribution of the other explanations and of investment in creditworthiness.

In the context of Overby's call to reemphasize equality of opportunity in financial services, the checking account data may be quite informative about the continuing lack of such equality. It seems unlikely that the strikingly different rates of checking accounts are due to blacks' simply having different tastes than whites, with those tastes unaffected by discrimination. The other apparent explanations for the checking account data all speak to continuing inequality of opportunity: lender discrimination 
magnified by lower investment in creditworthiness, fewer financial institutions in black neighborhoods, or lower average usefulness of checking accounts for blacks.

It is beyond the scope of this Paper to explore the policy implications of the investment in creditworthiness model. As a general matter, however, the model underscores the importance of educating consumers about financial services. Policy proposals might include government efforts to train consumers in how to use financial services, or giving full CRA credit to loan counselling programs and other outreach efforts.

In her article, Professor Overby helps us see the extent to which the CRA seeks the goal of equality of opportunity in lending markets. Equality of opportunity is historically linked to assuring a decent education for all people. The investment in creditworthiness discussion shows how a decent education in financial services may be more important than previously realized. 


\section{TECHNICAL APPENDIX}

\section{A. Data}

The data on checking accounts come from the 1989 Survey of Consumer Finances (the Survey), conducted for the Federal Reserve Board by the Survey Research Center at the University of Michigan. ${ }^{75}$ The Survey sampled 3143 households. The data presented here include only households responding to the race classification question as white or black. Those responses indicating Asian or Hispanic and those not responding to the race classification question were excluded. The data presented here also exclude responses to the Survey that were incomplete with respect to other variables reported in the regression results. The results presented include a total of 1960 responses.

In addition to race, the Survey data provide information about respondents' finances, human capital, and other demographic characteristics. The financial variables include income and net worth. The human capital variables include education (whether a person has completed high school), age (human capital increases with age), and employment (whether the head of household is currently employed). The other demographic variables include whether the household is headed by a single person, whether the household resides in a metropolitan area, and whether the head of the household is male. Because less than $1 \%$ of the responses reported a female head of household, that statistic is not reported, nor was it statistically significant in any regression run.

Table I reports the frequencies for all the categorical variables. Note that the checking account variable actually measures whether the head of the household has a checking account. It is theoretically possible that another member of a household has a checking account even though the head does not, but for expositional convenience I generally say that the household has a checking account.

${ }^{75}$ The design of the Survey is described in Kennickell \& Shack-Marquez, supra note 49 , at $17-18$. 


\section{TABLE I}

VARIABLES USED IN THE MODELS

\begin{tabular}{|c|c|c|}
\hline VARIABLE NAME & DESCRIPTION & VALUES AND FREQUENCY \\
\hline Race & $\begin{array}{l}\text { race of the head of the } \\
\text { household }\end{array}$ & $\begin{array}{l}0 \text { - white }(94.6 \%) \\
1 \text { - black }(5.4 \%)\end{array}$ \\
\hline Single & $\begin{array}{l}\text { whether the household } \\
\text { contains a married } \\
\text { couple }\end{array}$ & $\begin{array}{l}0 \text { - married }(96.6 \%) \\
1 \text { - single }(3.4 \%)\end{array}$ \\
\hline Metro Area & $\begin{array}{l}\text { metropolitan area or } \\
\text { rural }\end{array}$ & $\begin{array}{l}0 \text { - metro }(91.5 \%) \\
1 \text { - rural }(8.5 \%)\end{array}$ \\
\hline Employment & $\begin{array}{l}\text { whether the head of the } \\
\text { household is currently } \\
\text { employed }\end{array}$ & $\begin{array}{l}0 \text { - yes }(79.4 \%) \\
1 \text { - no }(20.6 \%)\end{array}$ \\
\hline Education & $\begin{array}{l}\text { whether the head of the } \\
\text { household has com- } \\
\text { pleted high school }\end{array}$ & $\begin{array}{l}0 \text { - yes }(84.8 \%) \\
1 \text { - no }(15.2 \%)\end{array}$ \\
\hline $\begin{array}{l}\text { Checking } \\
\text { Account }\end{array}$ & $\begin{array}{l}\text { whether the head of the } \\
\text { household has a check- } \\
\text { ing account }\end{array}$ & $\begin{array}{l}0-\text { no }(5.6 \%) \\
1-\text { yes }(94.4 \%)\end{array}$ \\
\hline
\end{tabular}

A potentially significant aspect of the data is that the proportion of black households to white households changes due to incomplete responses to the survey. Of the 2865 surveys of white and black households, black households comprised $10.7 \%$, and white households comprised the remaining $89.3 \%$. For all surveys used in the regressions (the 1960 of those 2865 that responded to each of the questions), the black households comprised $5.4 \%$ and white households comprised $94.6 \%$. The Federal Reserve, in reporting the proportion of black and all other households who had checking accounts in the 1989 Survey, used complex techniques for imputing responses to unanswered questions. For the regressions reported here, there was no similar way to use the incomplete surveys.

The black households included in the regressions were different from the full set of black households. For all 2865 black or white households in the survey, $50.9 \%$ of black households and $93.5 \%$ of white households had checking accounts. Indeed, blacks without 
checking accounts were $5.3 \%$ of the 2865 , while whites without checking accounts were only $5.8 \%$, even though whites constituted 89.3\% of that population. For the 1960 households used in the regressions, $75.2 \%$ of black households and $95.5 \%$ of white households had checking accounts. Blacks without checking accounts were $1.3 \%$ of the 1960 households, while whites without checking accounts were $4.2 \%$.

In short, the proportion of blacks with checking accounts rose in the population used for the regressions, while the proportion of those without checking accounts who were black fell. Both of these changes would tend to make race a less significant predictor of which families have checking accounts. Thus, the regressions reported here tend to understate the significance of race.

It is possible, however, that the failure to give complete answers to the Survey is somehow correlated with other financial or demographic variables. If so, it is possible that those other variables would gain explanatory power if all black households were included in the regressions and race would become less significant.

\section{B. Regression Results}

Table II reports the Probit estimates of determinants of a household having a checking account. The dependent variable is equal to unity if the household has a checking account, and equal to zero if it does not. The Probit coefficient and $t$-statistic are reported. A range of regressions was run using both the Probit and Logit methods, but the results were essentially the same using either method. Only Probit results are presented here.

Of the larger set of regressions actually run, three are presented in Table II. Model 1 includes only race and the financial variables of income and net worth. Model 2 adds the human capital variables of age, education, and employment. Model 3 adds the demographic variables of sex, marriage, and metropolitan residence. All three models provide the same high level of predictive success, accurately predicting between 1846 and 1848 out of 1960 results. The signs of the coefficients were all in the direction that theory would predict. That is, the variables that one would expect to produce more checking accounts actually did. 
TABLE II

DETERMinANTS OF HouseHOLd CHECKING ACCOUNT ${ }^{76}$

\begin{tabular}{||l|l|l|l||}
\hline VARIABLE NAME & $\begin{array}{c}\text { MODEL 1: } \\
\text { FINANCAL } \\
\text { VARIABLE }\end{array}$ & $\begin{array}{c}\text { MODEL 2: ADD } \\
\text { HUMAN CAPIAL } \\
\text { VARIABLES }\end{array}$ & $\begin{array}{c}\text { MODEL 3: ADD } \\
\text { DEMOGRAPHIC } \\
\text { VARIABLES }\end{array}$ \\
\hline \hline Race & $\begin{array}{c}-0.83 \\
(-5.50)^{* *}\end{array}$ & $\begin{array}{c}-0.75 \\
(-4.77)^{* *}\end{array}$ & $\begin{array}{c}-0.77 \\
(-4.88)^{* *}\end{array}$ \\
\hline Income & $\begin{array}{c}0.38 \\
(8.97)^{* *}\end{array}$ & $\begin{array}{c}0.32 \\
(6.67)^{* *}\end{array}$ & $\begin{array}{c}0.32 \\
(6.55)^{* *}\end{array}$ \\
\hline Net Worth & $\begin{array}{c}0.34 \\
(3.51)^{* *}\end{array}$ & $\begin{array}{c}0.25 \\
(2.18)^{*}\end{array}$ & $\begin{array}{c}0.25 \\
(2.23)^{*}\end{array}$ \\
\hline Age & & $\begin{array}{c}0.27 \\
(5.86)^{* *}\end{array}$ & $\begin{array}{c}0.24 \\
(5.23)^{* *}\end{array}$ \\
\hline Education & & -0.80 & $\begin{array}{c}-0.77 \\
(-5.99)^{* *}\end{array}$ \\
\hline Employment & & $\begin{array}{c}-0.34 \\
(-2.12)^{*}\end{array}$ & $\begin{array}{c}-0.31 \\
(-1.91)\end{array}$ \\
\hline Single & & & -0.45 \\
& & & -0.59 \\
\hline Metro Area & & & $-2.19)^{*}$ \\
\hline Constant & -2.44 & -2.69 & -2.18 \\
\hline
\end{tabular}

- significant at $5 \%$ level.

- significant at $1 \%$ level.

$N=1960 ;$ positive observations $(N)=$ between 1846 and 1848

The regressions support the hypothesis that race is a significant explanation for whether a household has a checking account. Race was statistically significant at the $1 \%$ level for all regressions run. The coefficient and significance of the race variable was invariant to

${ }^{76}$ Table II reports Probit coefficients and $t$-statistics (in parentheses). A variable for sex was included in the equation for Model 3, but was not reported. 
different combinations of included and excluded independent variables, and thus appears to be robust to model specifications.

Of the financial statistics, income was statistically significant at the $1 \%$ level for all models. Net worth was significant at the $1 \%$ level in some models, and the $5 \%$ level in others. Of the human capital statistics, age and education were statistically significant at the $1 \%$ level for all models. Employment was on the borderline of being significant at the $5 \%$ level. Of the demographic statistics, marriage was statistically significant at the $5 \%$ level. Residence in a metropolitan area was not statistically significant in any model. The very small number of female-headed households in the sample led to the exclusion of that variable from the reported results. 
